Situs Jurnal : $\underline{\text { http://ejournal.stiepancasetia.ac.id/index.php/jieb }}$

Jilid 5 Nomor 3 November 2019

Hal 386 - 394

\title{
PENGARUH KOMPENSASI, MOTIVASI KERJA, DAN KOMITMEN ORGANISASI TERHADAP KINERJA PERSONEL POLRI BIDDOKKES POLDA KALIMANTAN SELATAN
}

\section{Menik Sri Rahayu*, Achmad Firdiansjah, dan Harianto Respati}

Abstract: The purpose of the study was to analyze the effect of leadership motivation and job Polri Biddokkes Polda Kalsel always effort to improve work performance. It is influenced by compensation, motivation, and organizational commitment. To analyzing and to know the influence, the research needs to do in Polri Biddokkes Polda Kalsel. Quantitative method is used in this research. The population is all members of Polri Biddokkes Polda Kalsel. They are 63 persons. Technique of sampling is census. This research samples are 63 persons. The datas collection technique is questioner. Data is analyzed by linier regression analysis. The research result shows that compensation, motivation, and organizational commitment have influence significantly to the performance partially and simultance. Polri Biddokkes Polda Kalsel need to improve compensation, motivation, and organizational commitment to improve because these variables have influence significantly to the performance

Keywords: Performance, compensation, motivation, and organizational commitment

Abstrak: Tujuan dari penelitian ini adalah untuk menganalisis pengaruh motivasi kepemimpinan dan pekerjaan Polri Biddokkes Polda Kalsel yang selalu berupaya meningkatkan kinerja kerja. Itu dipengaruhi oleh kompensasi, motivasi, dan komitmen organisasi. Untuk menganalisis dan mengetahui pengaruhnya, perlu dilakukan penelitian di Polri Biddokkes Polda Kalsel. Metode kuantitatif digunakan dalam penelitian ini. Populasi adalah semua anggota Polri Biddokkes Polda Kalsel. Mereka adalah 63 orang. Teknik pengambilan sampel adalah sensus. Sampel penelitian ini adalah 63 orang. Teknik pengumpulan data adalah kuesioner. Data dianalisis dengan analisis regresi linier. Hasil penelitian menunjukkan bahwa kompensasi, motivasi, dan komitmen organisasi berpengaruh signifikan terhadap kinerja secara parsial dan simultan. Boldokkes Polda Kalsel Polri perlu meningkatkan kompensasi, motivasi, dan komitmen organisasi untuk meningkatkan karena variabel-variabel ini memiliki pengaruh signifikan terhadap kinerja.

Kata kunci: Kinerja, kompensasi, motivasi, dan komitmen organisasi

\section{Latar Belakang}

Salah satu tugas dan pekerjaan personel Polri yang memerlukan keahlian khusus di lembaga kepolisian adalah satker Biddokkes. Satker Biddokkes ini memegang peranan penting menunjang tugas dan pekerjaan personel Polri. Tugas dan tanggung jawab di bidang ini juga memerlukan kinerja personel Polri yang optimal. Biddokkes Polda Kalimantan Selatan mengupayakan peningkatan kinerja personel Polri guna menunjang peningkatan pelayanan kepada masyarakat. Kinerja personel Polri Biddokkes Polda Kalimantan Selatan sudah baik, namun upaya untuk meningkatkan kinerja terus diupayakan. Peningkatan kinerja ini tentu dipengaruhi oleh beberapa variabel. Peningkatan kinerja dapat diupayakan jika mengetahui 
variabel yang mempengaruhinya. Polda Kalimantan Selatan khususnya Satker Biddokkes, perlu menganalisis variabel yang dapat mempengaruhi peningkatan kinerja personelnya.

Kinerja dipengaruhi kompensasi di tempat kerja. Karyawan atau pegawai diberikan penghargaan finansial dan non finansial oleh organisasi atau lembaga tempat bekerja berdasarkan tugas dan hasil pekerjaan yang telah dilakukan. Kompensasi berbentuk gaji, pemberian hari libur, dan bonus. Kompensasi diberikan sesuai dengan kinerja pegawai. Kinerja yang dicapai sesuai dengan kompensasi yang diberikan organisasi. Kompensasi efektif jika dapat memotivasi karyawan dan meningkatkan produktivitas kerja. Kompensasi diberikan tidak berasarkan senioritas atau jam kerja. Kompensasi diprogramkan untuk meningkatkan motivasi kerja karyawan (Wibowo, 2016).

Motivasi juga berpengaruh terhadap kinerja karyawan atau pegawai. Karyawan maupun pegawai harus selalu dimotivasi agar kinerja yang dihasilkan meningkat. Motivasi dapat dipastikan mempengaruhi kinerja, walaupun bukan satu-satunya faktor yang membentuk kinerja (Wibowo, 2011). Kebutuhan adanya kekurangan fisiologis atau psikologis yang menimbulkan perilaku. Maslow menyatakan bahwa kebutuhan manusia berjenjang dari psysiological, safety, social, dan self actualization (Wibowo, 2011).

Selain itu, kinerja dipengaruhi komitmen organisasi, selain kompensasi, dan motivasi. Komitmen organisasi pegawai atau karyawan ditunjukkan dalam sikap penerimaan, keyakinan yang kuat terhadap nilai-nilai dan tujuan organisasi. Pegawai atau karyawan memiliki dorongan yang kuat untuk mempertahankan dan menjadi bagian penting dari anggota organisasi demi tercapainya tujuan organisasi. Komitmen ini akan mempengaruhi kinerja pegawai atau karyawan (Priansa, 2014).

Dengan demikian kinerja dipengaruhi oleh kompensasi, motivasi kerja, dan komitmen organisasi. Peningkatan kompensasi, motivasi kerja, dan komitmrn dapat meningkatkan kinerja. Sebaliknya menurunnya kompensasi, motivasi kerja dan komitmen kerja akan menurunkan kinerja. Penelitian terdahulu pun telah membuktikan pengaruh kompensasi, motivasi kerja, dan komitmen kerja terhadap kinerja.

\section{Kajian Literatur}

Kinerja adalah istilah yang populer di dalam manajemen, yang mana istilah kinerja didefinisikan dengan istilah hasil kerja, prestasi kerja dan performance. Kinerja adalah penampilan yang melakukan, menggambarkan dan menghasilkan sesuatu hal, baik yang bersifat fisik dan non fisik yang sesuai dengan petunjuk, fungsi dan tugasnya yang didasari oleh pengetahuan, sikap dan keterampilan (Dedi, 2010).

Para ahli memberikan beberapa pengertian kinerja. Kinerja adalah pekerjaan yang dapat dikerjakan oleh pekerja sesuai dengan tugas dan fungsinya. Kinerja adalah hasil kerja yang dapat ditampilkan seorang karyawan. Kinerja seorang karyawan dapat diukur dari hasil kerja, hasil tugas, atau hasil kegiatan dalam kurun waktu tertentu (Notoatmodjo, 2009).

Kompensasi adalah segala sesuatu yang diterima oleh karyawan sebagai balas jasa untuk kerja atau pengabdian mereka. Masalah kompensasi merupakan hal yang sangat kompleks, namun paling penting bagi karyawan maupun organisasi itu sendiri.Pemberian kompensasi kepada karyawan harus mempunyai dasar yang logis dan rasional (Notoadmodjo, 2009).

Kompensasi merupakan imbalan atau balas jasa yang diberikan oleh perusahaan kepada karyawannya yang dapat dinilai dengan uang. Kompensasi atau imbalan ini termasuk di dalamnya upah, gaji, insentif, komisi, dan sebagainya yang mengikat karyawan sehingga karyawan mau dan senang bekerja. Kompensasi ini harus menarik dan dapat menimbulkan keterikatan karyawan terhadap perusahaan, harus adil, harus dinamis, tidak kaku, harus dapat ditinjau kembali sesuai dengan prestasi karyawan (Alma, 2008). 
Jadi kompensasi adalah semua pendapatan yang berbentuk uang atau barang langsung atau tidak langsung yang diterima karyawan sebagai imbalan atas jasa yang diberikan kepada perusahaan atau lembaga tertentu. Kompensasi adalah segala sesuatu yang diterima oleh karyawan sebagai balas jasa untuk kerja atau pengabdian mereka.

Motivasi sering, diartikan dengan istilah dorongan, yang berarti tenaga yang menggerakkan jiwa dan jasmani untuk berbuat sehingga motif merupakan "driving force" seseorang, untuk bertingkah laku dalam mencapai tujuan yang telah ditetapkan. Setiap orang mempunyai motif diri yang berbeda antara orang yang satu dengan yang lainnya (Marnis, 2014).

Motivasi adalah kekuatan kecendrungan seseorang atau individu melibatkan diri dalam kegiatan yang mengarah kepada pekerjaan tertentu. Pengertian motivasi menurut Terry adalah keinginan yang terdapat pada diri seseorang individu yang mendorongnya untuk melakukan perbuatan-perbuatan (perilaku) tertentu (Notoatmodjo, 2009).

Jadi motivasi adalah keseluruhan proses pemberian motivasi bekerja kepada bawahan sedemikian rupa sehingga mereka mau bekerja dengan ikhlas. Upaya mencapai tujuan organisasi diharapkan dapat berjalan efisien dan ekonomis.

Komitmen organisasi (Organizational Commitment) adalah sikap yang mencerminkan sejauh mana seseorang individu mengenal dan terikat pada organisasi. Karyawan yang memiliki komitmen yang tinggi kemungkinan akan melihat dirinya sebagai anggota sejati organisasi (Widhiastuti, 2012).

Priansa (2014) menjelaskan bahwa komitmen organisasi adalah keinginan kuat untuk tetap sebagai anggota organisasi tertentu, keinginan untuk berusaha keras sesuai dengan keinginan organisasi, serta menerima nilai dan tujuan organisasi. Komitmen organisasikap merefleksikan loyalitas karyawan pada organisasi dan proses berkelanjutan dimana anggota organisasi mengekspresikan perhatiannya terhadap organisasi dan keberhasilan serta kemajuan yang berkelanjutan. Komitmen organisasi adalah kesediaan seseorang untuk mengikatkan diri dan menunjukkan loyalitas pada organsiasi karena merasakan dirinya terikat dalam kegiatan organisasi (Wibowo, 2016).

Jadi komitmen organisasi adalah loyalitas pegawai terhadap organisasi yang tercermin dari keterlibatannya yang tinggi untuk mencapai tujuan organisasi. Loyalitas pegawai ditunjukkan melalui kesediaan dan kemauan berusaha menjadi bagian dari organisasi serta keinginan yang kuat untuk bertahan dalam organisasi.

\section{Metode Penelitian}

Populasi adalah keseluruhan objek yang menjadi sasaran penelitian (Wahyuni, 2011: 4). Populasi penelitian ini adalah semua personel Polri Biddokkes Polda Kalimantan Selatan yang berjumlah 73 orang.Menetapkan besar/ukuran sampel ini penulis menggunakan teori dari Suharsimi Arikunto (2006) yang mengemukakan untuk sekedar ancer-ancer apabila subyeknya kurang dari 100 orang lebih baik diambil semuanya, sehingga penelitiannya merupakan penelitian populasi. Selanjutnya jika subyeknya lebih besar dapat diambil $10-15 \%$ atau 20 $25 \%$ atau lebih tergantung dari kemampuan peneliti dilihat dari segi waktu, tenaga, dana, dan sebagainya.

Menurut Wahyuni (2011) sampel penelitian adalah bagian dari populasi yang menjadi objek penelitian. Teknik pengambilan sampel menggunakan bertujuan, artinya semua populasi dijadikan sampel penelitian dipilih berdasarkan sampel yang dikehendaki berdasarkan argumen tertentu. Sampel penelitian ini personel Polri Biddokkes bukan honorer dan bukan pimpinan Biddokkes, berjumlah 63 orang. 
Teknik pengumpulan data penelitian ini menggunakan Kuisioner. Kuisioner adalah cara pengumpulan data dengan menggunakan daftar pertanyaan (angket) atau daftar isian tentang objek yang diteliti (populasi atau sampel) (Misbahuddin dan Hasan, 2013). Instrumen penelitian menggunakan angket yaitu angket untuk kinerja (Y), kompensasi (X1), motivasi kerja (X), dan komitmen organisasi (X3).

Analisis data penelitian ini menggunakan analisis regresi linier ganda. Regresi berganda merupakan analisis yang digunakan untuk mengetahui pengaruh variabel bebas terhadap variabel terikat. Penelitian ini juga menganalisis deskripsi atau gambaran, kompensasi, motivasi, komitmen organsiasi, dan kinerja karyawan.

1. Analisis Deskriptif

Gambaran kompensasi, motivasi kerja, komitmen organsiasi, dan kinerja personel Polri Biddokkes Polda Kalimantan Selatan dianalisis dengan analisis deksiripsi. Analisis deskripsi dilakukan dengan menghitung frekuensi, rata-rata, dan persentase.

2. Analisis Regresi Linier Berganda

Analisis regresi berganda merupakan perluasan dari regersi sederhana yaitu dengan menambah jumlah variabel bebas (regresi berganda) (Sanusi, 2012). Analisis regresi dilakukan dengan menggunakan aplikasi SPSS versi 20.

a. Uji Asumsi Klasik

Uji prasyarat atau uji asumsi adalah sesuatu yang dikenakan pada kelompok data hasil observasi atau penelitian untuk mengetahui layak atau tidaknya data tersebut dianalisis dengan menggunakan teknik statistik (Misbahuddin dan Hasan, 2013L 276). Uji asumsi klasik dilakukan dengan melakukan uji Normalitas Data, Heterokedasitas, dan Multikolinieritas.

b. Analisis Regresi

1) Uji Koefisien Determinan $\left(R^{2}\right)$

Uji ini digunakan untuk menentukan persentase variabel bebas mempengaruhi variabel terikat. Uji juga digunakan mengetahui persentase eror.

2) Uji Pengaruh Simultan (Uji F)

Uji ketepatan model atau disebut juga uji $\mathrm{F}$ dilakukan untuk mengetahui ketepatan model penelitian ini. Jika Nilai $F$ hitung $>$ F tabel dan signifikansi $<0,05$, maka model penelitian ini layak. Uji $\mathrm{F}$ juga digunakan untuk menguji pengaruh simultan yaitu pengaruh kompensasi, motivasi kerja, dan komitmen organisasi terhadap kinerja.

3) Uji Pengaruh Parsial (Uji t)

Uji t ini digunakan untuk mengetahui pengaruh parsial variabel bebas terhadap vatiabl terikat dalam penelitian ini. Jika Nilai $t$ hitung $>\mathrm{t}$ tabel dan signifikansi $<0,05$, maka hipotesis parsial penelitian diterima. Uji t digunakan untuk menguji pengaruh kompensasi, motivasi kerja, dan komitmen organisasi terhadap kinerja secara parsial.

4) Persamaan garis regresi ganda 2 variabel bebas

$\mathrm{Y}=\mathrm{a}+\mathrm{b}_{1} \mathrm{X} 1+\mathrm{b}_{2} \mathrm{X} 2+\mathrm{b}_{3} \mathrm{X} 3+\mathrm{e}$

a : konstanta

$\mathrm{b}_{1}$ : Koefisien regresi Kompensasi

$\mathrm{b}_{2}$ : Koefisien regresi Motivasi Kerja

$b_{3}$ : Koefisien regresi Komitmrn organissi

e : eror 
secara skematis kerangka konseptual dalam penelitian ini yang dapat ditunjukkan seperti Gambar 1.

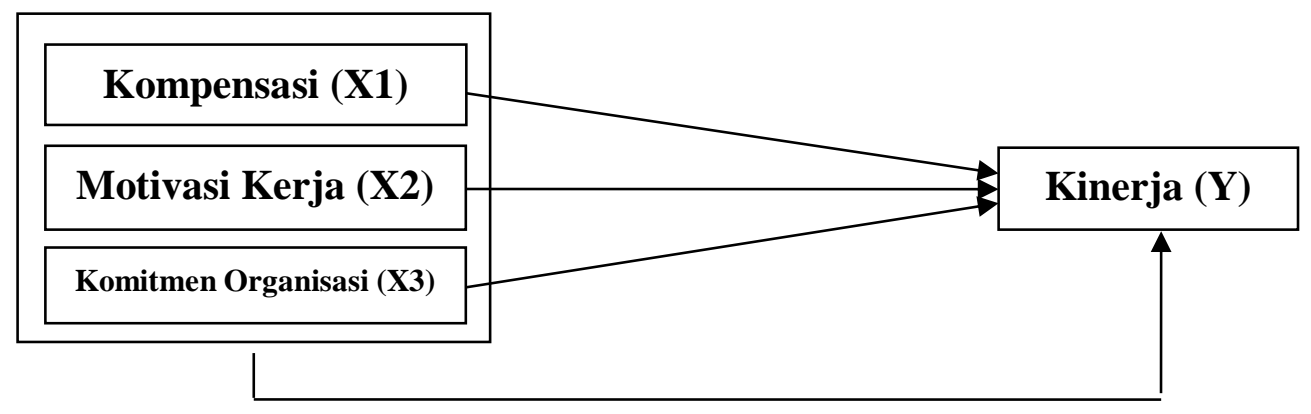

\section{Gambar 1. Kerangka Konseptual Penelitian}

\section{Hasil Penelitian dan Pembahasan}

Normalitas data dapat diketahui melalui diagram P-P Plot regresi. Jika titik-titik mengikuti garis regresi, maka data dinyatakan berdistribusi normal. Hasil analisis regresi P-P Plot penelitian ini menunjukkan titik-titik mengikuti garis lurus sehingga data penelitian ini berdistribusi normal seperti gambar 2 .

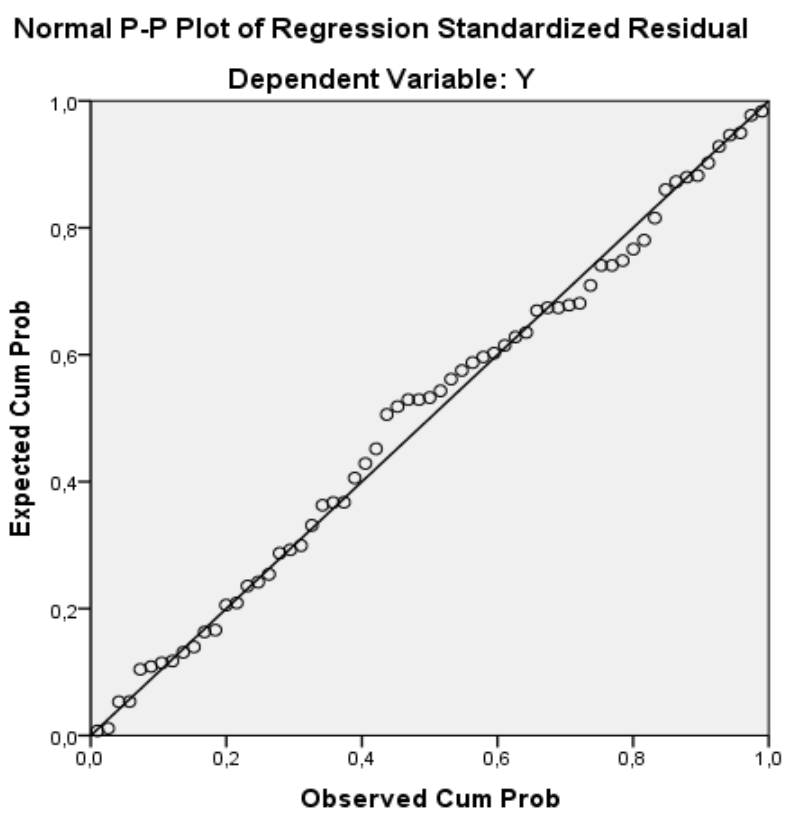

\section{Gambar 2. Normal P-Plot Regression Standardized Residual}

Heterokedastisitas terjadi jika diagram pancar hasil analisis regresi membentuk suatu pola. Jika diagram pancar tidak membentuk pola tertentu, maka tidak terjadi gejala heterokedastisitas. Diagram berikut ini menunjukkan bahwa data kompensasi (X1), motivasi (X2), dan komitmen (X3) tidak mengalami gejala heterokedastisitas karena diagram pancar masing-masing tidak membentuk pola tertentu seperti garis lurus atau lingkaran. 


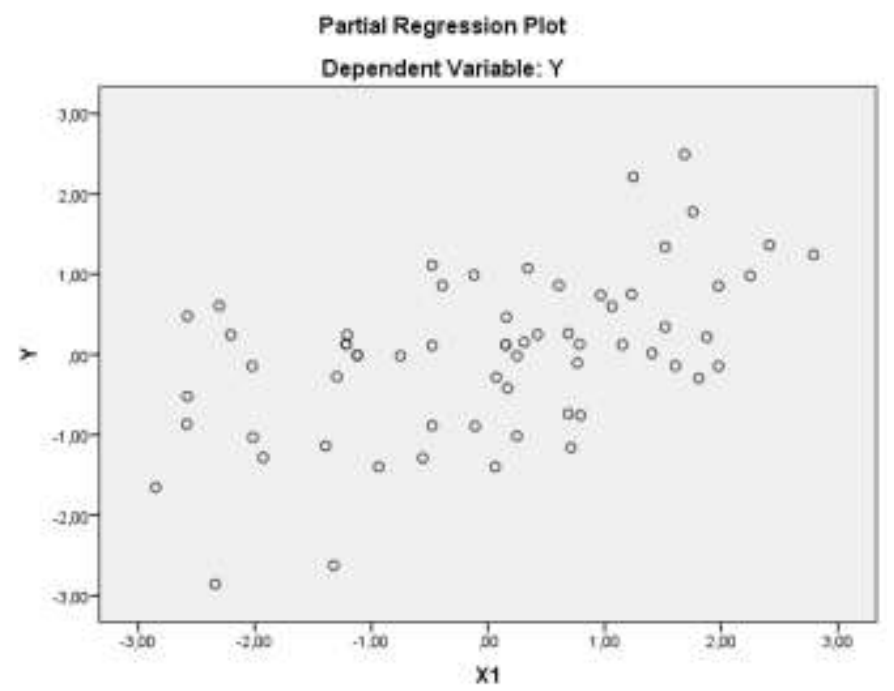

\section{Gambar 3. Diagram Pancar X1}

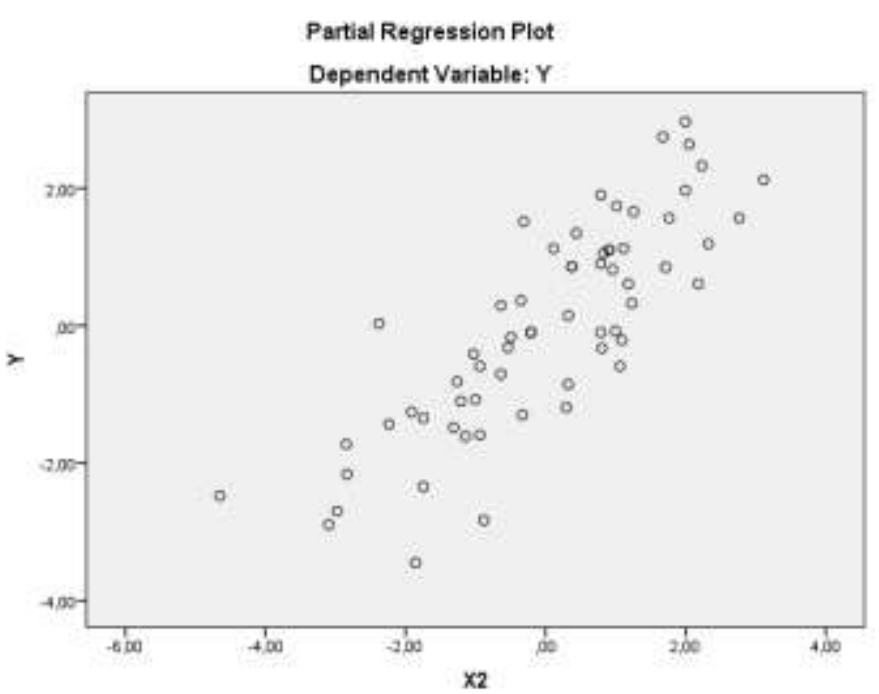

Gambar 4. Diagram Pancar X2

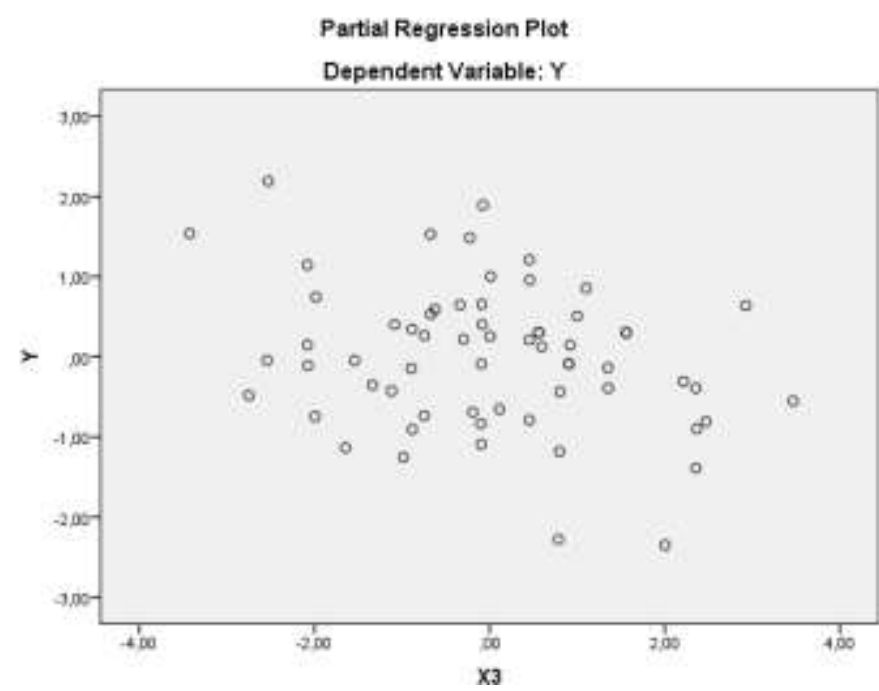




\section{Gambar 5. Diagram Pancar X3}

Hasil uji multikolinieritas ditunjukkan pada Tabel 1.

Tabel 1. Hasil Uji Multikolinieritas

\begin{tabular}{clcl}
\hline No. & \multicolumn{1}{c}{ Variabel } & VIF & Kriteria \\
\hline 1. & Kompensasi (X1) & 4,203 & \\
\cline { 1 - 2 } 2. & Motivasi $(\mathrm{X} 2)$ & & VIF $<10$ \\
\cline { 1 - 2 } 3. & Komitmen Organisasi $(\mathrm{X} 3)$ & 2,765 & \\
\hline
\end{tabular}

Tabel 1 menunjukkan hasil uji multikolinieritas. Data penelitian dinyatakan terbebas dari multikolinieritas jika nilaii VIF < 10. Nilai VIF pada kompensasi (X1) mencapai 4,203, VIF Motivasi (X2) mencapai 5,480, dan nilai VIF Kepuasan kerja (X3) mencapai 2,765. Semua variabel bebas penelitian memiliki nilai VIF $<10$. Jadi data penelitian ini tidak mengalami multikolinieritas.

Hasil analisis regresi linier berganda penelitian ini menunjukkan nilai R dan R2. Nilai R sebesar 0,973 dan nilai R2 sebesar 0,946. Nilai R sebesar 0,973 dikuadratkan menjadi 0,946. Ini menunjukkan bahwa variabel kinerja Polri Biddokkes Polda Kalsel dipengaruhi oleh variabel kompensasi, motivasi, dan komitmen organisasi sebesar 94,6\%. Sisanya 5,4\% kinerja Polri Biddokkes Polda Kalsel dipengaruhi oleh variabel yang lainnya di luar model penelitian ini.

Persentase pengaruh ketiga variabel ini besar terhadap kinerja Polri Biddokkes Polda Kalsel. Pengaruh variabel lain selain kompensasi, motivasi dan komitmen kecil sekali hanya $5,4 \%$. Namun yang penting diperhatikan adalah pengaruh ketiga variabel yang besar ini terjadi bersamaan bukan parsial. Berikut ini terlihat pada tabel hasil koefisien regresi penelitian, seperti ditunjukkan pada Tabel 2.

Tabel 2 Koefisien Regresi

\begin{tabular}{cccccc}
\hline No. & Pengaruh Parsial & Korfisien Regresi & thitung & Signifikansi & Kesimpulan \\
\hline 1. & $\mathrm{X} 1-\mathrm{Y}$ & 0,363 & 4,700 & 0,000 & $\begin{array}{c}\text { Berpengaruh } \\
\text { Signifikan }\end{array}$ \\
\hline 2. & $\mathrm{X} 2-\mathrm{Y}$ & 0,777 & 11,262 & 0,000 & $\begin{array}{c}\text { Berpengaruh } \\
\text { Signifikan }\end{array}$ \\
\hline 3. & $\mathrm{X} 3-\mathrm{Y}$ & $-0,171$ & $-2,284$ & 0,026 & $\begin{array}{c}\text { Berpengaruh } \\
\text { Signifikan }\end{array}$ \\
\hline 4. & Konstanta & & \multicolumn{2}{c}{2,381} & \\
\hline
\end{tabular}

Tabel 2 menunjukkan kompensasi berpengaruh terhadap kinerja sebear 0,000. Nilai signifikansi $0,000<0,05$. Jadi kompensasi berpengaruh signifikan terhadap kinerja Polri 
Biddokkes Polda Kalsel. Nilai signifikansi hitung pengaruh motivasi terhadap kinerja sebesar 0,000. Nilai signifikansi ini $<0,05$. Motivasi berpengaruh signifikan terhadap kinerja Polri Biddokkes Polda Kalsel. Nilai signifikansi hitung pengaruh komitmen organisasi terhadap kinerja sebesar 0,026. Nilai signifikansi ini $<0,05$. Komitmen organisasi juga berpengaruh signifikan terhadap kinerja Polri Biddokkes Polda Kalsel. Garis persamaan regresi hasil penelitian ini:

$\mathrm{Y}=2,381+0,363 \mathrm{X} 1+0,777 \mathrm{X} 2+(-0,171) \mathrm{X} 4+\mathrm{ero}$

Tabel 2. Anova

\begin{tabular}{llll}
\hline df & Mean Square & F & Sig. \\
\hline 3 & 266,579 & 344,213 & $0,000^{\mathrm{b}}$ \\
\hline 59 & 0,774 & & \\
\hline 62 & & & \\
\hline
\end{tabular}

Tabel 3 menunjukan hasil uji anova. Nilai F hitung penelitian ini 344,213. Nilai F tabel diketahui dengan mengecek tabel $\mathrm{F}$ dengan taraf kepercayaan $5 \%$ atau 0,05 . Nilai $\mathrm{F}$ tabel pada df-3 dan df-59 menunjukkan 2,76. Ini berarti F hitung > F tabel. Sementara signifikansi 0,000 $<0,05$. Dengan demikian model penelitian ini sudah tepat dan layak. Hipotesis yang menyatakan bahwa kompensasi, motivasi, dan komitmen organisasi berpengaruh signifikan terhadap kinerja Polri Biddokkes Polda Kalsel diterima secara simultan.

\section{Kesimpulan dan Keterbatasan Penelitian}

Berdasarkan hasil analisis data dan pembahasan yang telah dikemukakan di atas, Berdasarkan hasil analisis dan pembahasan yang dikemukakan di atas, disimpulkan sebagai berikut.

1. Kompensasi di Polri Biddokkes Polda Kalsel sangat baik. Motivasi kerja Polisi ini baik. Komitmen organisasi polisi ini sangat baik.

2. Kompensasi berpengaruh signifikan terhadap kinerja Polri Biddokkes Polda Kalsel.

3. Motivasi kerja berpengaruh signifikan terhadap kinerja Polri Biddokkes Polda Kalsel.

4. Komitmen Organisasi berpengaruh signifikan terhadap kinerja Polri Biddokkes Polda Kalsel.

5. Motivasi kerja, berpengaruh dominan terhadap kinerja Polri Biddokkes Polda Kalsel.

Berdasarkan kesimpulan di atas, dikemukakan saran-saran kepada anggota Polri Biddokkes Polda Kalsel dan pihak pimpinan Polri Biddokkes Polda Kalsel.

1. Anggota Polri Biddokkes Polda Kalsel perlu meningkatkan motivasi dan komitmen terhadap pekerjaan sebagai polisi karena peningkatkan ini berrpengaruh signifikan terhadap kinerja.

2. Pimpinan atau pihak berwenang dapat meningkatkan kinerja anggota Polri Biddokkes Polda Kalsel melalui upaya meningkatkan kompensasi, motivasi, dan komitmen organisasi.

\section{DAFTAR PUSTAKA}

Alma, Buchari.2008. Pengantar Bisnis. Bandung: Alfabeta.

Dedi, Rianto Hadi. 2010. Manajemen Kinerja. Malang: Tunggal Mandiri Publlishing. 
Larasati, 2014. Pengaruh Motivasi Kerja terhadap Kinerja Karyawan Wilayah Telkom Jabar Barat Utara (Witel Bekasi) (Online) diakses dari Jurnal Manajemen dan Organisasi Vol V, No 3, Desember 2014.

Kasmir. 2011. Kewirausahaan. Jakarta : PT Raja Grafindo Persada.

Marnis, Priyono. 2014. Manajemen Sumber Daya Manusia. Sidoarjo: Zifatama Publishing

Misbahuddin dan Iqbal Hasan. 2013. Analisis Data Penelitian dengan Statistik. Jakarta: Bmi Aksara.

Noor, Juliansyah. 2015. Analisis Data PenelitianEkonomi dan Manajemen. Jakarta: PT Grasindo.

Notoatmodjo, Soekidjo. 2009. Pengembangan Sumber Daya Manusia. Jakarta: PT Rineka Cipta.

Priansa. D. J. 2014. Perencanaan dan Pengembangan SDM. Bandung: Alfabeta.

Rahadi, Dedi Rianto. 2010. Penialaian Kinerja. Malang: Tunggal mandiri Publishing.

Rahmayanti. 2014. Pengaruh Motivasi Kerja terhadap Kinerja Karyawan pada CV Putra Kaltim Samarinda. Jurnal. Diakses dari e Journal Ilmu Administrasi Bisnis, 2014.

Riana, dkk. 2016. Pengaruh Kompensasi terhadap Kinerja Karyawan di Kampung Batu Malakasari Tektona Waterpark Kabupaten Bandung. (Online) diakses dari Tourism Scientific Journal Volume 2 Nomor 1 Desember 2016.

Robbin, Stephen P. 2008. Perilaku Organisasi. Jakarta : Salemba Empat.

Samsuddin, Sadli.2006. Manajemene Sumber Daya Manusia, Bandung: CV Pustaka Setia.

Sapitri, Ranty. 2016. Pengaruh Komitmen Organisasi terhadap Kinerja Karyawan Perusahaan Listrik Negara Area Pekanbaru. Jurnal. Diakses dari JOM Fisip Vol. 3 No. 2 - Oktober 2016

Sedarmayanti. 2009. Manajemen Sumber daya Manusia. Bandung: PT Refika Aditama.

Siagian, Sondang P. 2008. Manajemen Sumber Daya Manusia. Jakarta: Bumi Aksara.

Sunyoto, Danang. 2012. Teori. Kuisioner, dan Analisis Data Sumber Daya Manusia. Yogyakarta : CAPS.

Theodora, Olivia. 2015. Pengaruh Motivasi Kerja terhadap Kinerja Karyawan PT Sejahtera Motor Gemilang. Journal AGORA Vol. 3, No. 2, (2015)

Tiyanto, P. 2010. Tantangan Manajemen Sumberdaya Manusia Abad 21. Semarang : Untag

Triton. 2009. Mengelola Sumber Daya Manusia. Yogyakarta: Oryza.

Wahyuni, Y. 2011. Dasar-Dasar Statistik Deskriptif.Yohyakarta: Nuha Medika.

Wibowo. 2011. Manajemen Kinerja. Jakarta: Rajawali Pers.

Widhiastuti, Hardani. 2012. Membangun Loyalitas Sumber Daya Manusia. Semarang: Semarang Universitas press.

Zaenuri, M. 2015. Manajemen Sumber Daya Manusia di Pemerintahan. Yogyakarta: LP3K Universitas Muhammadiyah Yogyakarta. 